\title{
IKAP.P
}

JKAP (Jurnal Kebijakan dan Administrasi Publik) Vol.21 (1), May 2017, 13-28

ISSN 0852-9213 (Print), ISSN 2477-4693 (Online)

Available Online at https://journal.ugm.ac.id/jkap

\section{A Study of Good Governance Index in Yogyakarta Special Region Between 2012 and 2016}

\author{
Achmad Ubaidillah \\ The Graduate School of East Asian Studies, Yamaguchi University \\ a.ubaidillah.y@gmail.com
}

\begin{abstract}
This study assesses the progress of good governance index in Yogyakarta between 2012 and 2016. Kemitraan (Partnership for Governance Reform) developed the Yogyakarta governance index of 2012 based on the IGI (Indonesia Governance Index)'s methodology. The author used the same methodology to develop Yogyakarta governance index of 2016 based on newly collected data on government, bureaucracy, civil society and economic society in Yogyakarta. This paper compares Yogyakarta good governance index for 2012 and 2016. The index comprises scores on three levels, interalia: the arena, principles and actual policy. The paper introduces and describes the three tier structure and index processing. Results of the comparison of the index for 2012 and 2016 shows that in general Yogyakarta governance index increased from the level of fairy good (6.80) in 2012 to good (7.93) in 2016. Subsequently, the scores that comprise the arena and principle levels were analyzed to determine the contribution of each to the total governance index, and afterwards determine the contribution of each principle to the score of each arena. The results of the analysis procedure indicates the possibility that the increase in governance index may be linked to new special status Law No.13 of 2012 for Yogyakarta. Prior to 2012, the special status of Yogyakarta special administration was shrouded in uncertainty. However, with the passage of Law No.13/2013, the special status of the province is now codified, and today forms the legal basis for policy making in this province. This paper limits itself to indicators that point to the association between the governance and the enactment of the law, and does neither go as far as analyzing the impact that the enactment of the special status law has had on policies, nor evaluate the impact that policy changes made in the aftermath of the implementation of the special status law on the performance of the index.
\end{abstract}

Keywords: good governance, decentralization, good governance of Yogyakarta 


\section{INTRODUCTION}

Yogyakarta Special Region was formed after a merger agreement between Yogyakarta Sultanate and Paku Alaman Kingdoms o one hand, and the Indonesia government on the other, signed on $19 \mathrm{Au}$ gust 1945 (two days after Indonesia's independence). Yogyakarta Sultanate was established in 1755 by the Prince Mangku Bumi (Sri Sultan Hamengku Buwono I). Yogyakarta sultanate was a local self-government which was called Zelfbestuur landschappen/ autonomous region. During the Dutch colonial administration, the political agreement/ recognition Yogyakarta Sultanate as a local self-government was listed in Staatsblad No. 47 of 1941. Meanwhile, Paku Alaman Sultanate, which was also Zelfbestuur landschappen/autonomous region was established in 1813 by Prince Notokusumo (Paku Alam). Paku Alaman was also. The agreement that recognized Paku Alaman as a local self-government was listed in Staatsblad No. 577 of 1941.

Geographically, Yogyakarta province is located approximately between $7^{\circ} 49^{\prime} 26^{\prime \prime}$ - $7^{0} 50^{\prime} 84^{\prime \prime}$ south latitude and $110^{\circ} 23^{\prime} 79^{\prime \prime}-$ $110^{\circ} 28^{\prime} 53^{\prime \prime}$ east longitude. The province has five districts, namely Sleman, Bantul, Kulon Progo, Gunung Kidul, and Yogyakarta as the city center. The Province of Yogyakarta Special Region (DIY) is located in the southern central part of Java Island and bordering the Central Java province.

Yogyakarta showed a lot of commitment and support for the establishment of the Republic of Indonesia. Sri Sultan Hamengku Buwono IX and Sri Paku Alam VIII declared to the Sukarno President (first Indonesian president) that the Sultanate region and Paku Alaman become part an integral part of the Republic of Indonesia as a Special Region of Yogyakarta through a charter in 19 August 1945. The existence of Yogyakarta as an integral part of the Republic of Indonesia was formally stipulated in the Law No. 3/ 1950 on the "Establishment of Yogyakarta Special administrative Region". The Constitution of the Republic of Indonesia (UUD 1945) Article $18 \mathrm{~b}$ paragraph (1) stipulates the recognition of the existence of regions that are special, and the authority and governance of some special regions in Indonesia, that include 1). Jakarta as the special region of capital city; 2). Special Region of Aceh; 3). Special Region of Yogyakarta; 4). Maluku; and 5) Irian Jaya.

The special nature of Yogyakarta was also recognized in all local government legislations as evidenced in Law No. 32/ 2004,specifically Article 2, paragraph (8) and (9) that stipulates that:

\section{The definition of government units that are special are the areas that are giv- en special autonomy, while privileged area are of Aceh and Yogyakarta. (Article 2 paragraph (8) of Law No. 32/2004) \\ The State recognizes and respects units' customary law communities and their traditional rights all still alive and in accordance with the develop- ment of society and the principles of the Unitary Republic of Indonesia. (Article 2 paragraph (9) of Law No. 32/2004)}

However, as the product of previous legislation, Law No. 32 of 2004 does not specifically contain stipulation on forms and nature of privileges Yogyakarta province has such as those relating to procedures for filling position, duties, and authority of the Governor and Vice Governor.

In the wake of Suharto's downfall in 1998 (reformation period), good governance reform in Indonesia efforts got underway. One of the foundations of governance reform was the enactment of the decentralization Law No. 22/1999, which laid the framework on which the devolution of administrative and fiscal authority from the central government to local governments was based.

According to Utomo, (2012:1), "the intention of decentralization in Indonesia was not only to transform the governmental structure from centralized to decentralized but also to restore the pattern of relationships among actors of development, i.e. to build and to strengthen the implementation of good governance in central and local government.". The enactment of Law No. 22/f 1999, provided the legal framework for the devolution of authority, resources and 
responsibilities from the central government to local government (province and city/ district). However, the transition from centralized to decentralized government has not been easy for local governments (province and city/district), due to limited human resources capacity and ineffective institutions.

Therefore, during the transition phase of decentralization in Indonesia as reported by Green (2005:9), the process failed to fully meet the World Bank's criteria of being categorized as "successful". Nonetheless, after the transition phase, coupled with reforms in local government institutions and human resource capacity, decentralization eventually got on the right track. This is reflected in the improvement in good governance index as reported by the World Bank (Figure 1). This is close to the objective of decentralization as Green (2005:2) notes that the process should result in a more participatory government for citizens and improved delivery of public services due to better local participation and accountability.

The enactment of special legislation for the special provinces in Indonesia is one of the ways that support the implementation of good governance at the local government level. This is manifested in special region laws such as Law No. 34 / 1999 on Jakarta special capital city region of ; Law No. 44 / 1999 concerning the implementation of Aceh special Province ; and Law No. 21/ 2001 on Papua Province special regional autonomy.. Thus, until the enactment of Law No.13/2012, it was only Yogyakarta special province that did not have a law that stipulates its privileged position in relation to other provinces in Indonesia.

Furthermore, before the enactment of Law No. 13 of 2012, there was serious debate on several issues that included:

a. In 2004 and 2009, political parties and Indonesia society nominated Sultan Hamengku Buwono $\mathrm{X}$ as a candidate for the position of President of Indonesia. However, the candidature was hampered by lack of clarity on the status of Yogyakarta province since 1945, which has been used by successive Indonesian governments for bargaining power purposes.

b. No legislation that regulates local gov- ernment, that is Law No. 5 / 1969, Law No. 5 / 1974, Law No. 22 / 1999, Law No. 32 / 2004 on Regional Government has been able to specifically stipulate provisions that are tailored toward protecting the original and inalienable rights Yogyakarta special region that are embedded in in the 1945 Constitution .

c. The unfamiliarity of the successors of independence (next generation) to the history of Yogyakarta Sultanate and the Republic of Indonesia have created misunderstanding in the interpretation of the government and democratic system in Yogyakarta. It raises the merits and demerits of the governance and democracy system of in Yogyakarta.

The culmination of the public polemic on Yogyakarta special status, was the statement issued by President Susilo Bambang Yudhoyono that contended that the status of Yogyakarta is the privilege of a monarchy system, which is contrary to democratic values and constitutional governance. It is a statement that aroused diverse reactions from various elements of Yogyakarta society. The demonstration of members of Yogyakarta society which was re-incensed by the statement President Susilo Bambang Yudhoyono issued concerning the special status of Yogyakarta. The demonstrators demanded the government to confer the status of a special administrative province to the province or a referendum for Yogyakarta Independence from Indonesia.

Nonetheless, in the wake of the enactment of Law No. $13 / 2012$ concerning Yogyakarta Privileged position, the polemics in Yogyakarta province subsided. President Susilo Bambang Yudhoyono signed the Law No. 13 / 2012 on August $13^{\text {th }}, 2012$. The contents of which, among others stipulate: (A summary of the main contents can do, rather than using bullets). The following paragraph conveys the message concisely.

a. Procedures on fulfill the position, status, tasks and authority of the governor and vice governor; Governor and Vice Governor of Yogyakarta province are Sultan Hamengku Buwono and Paku Alam who reigns.

b. Regional government institution; the 


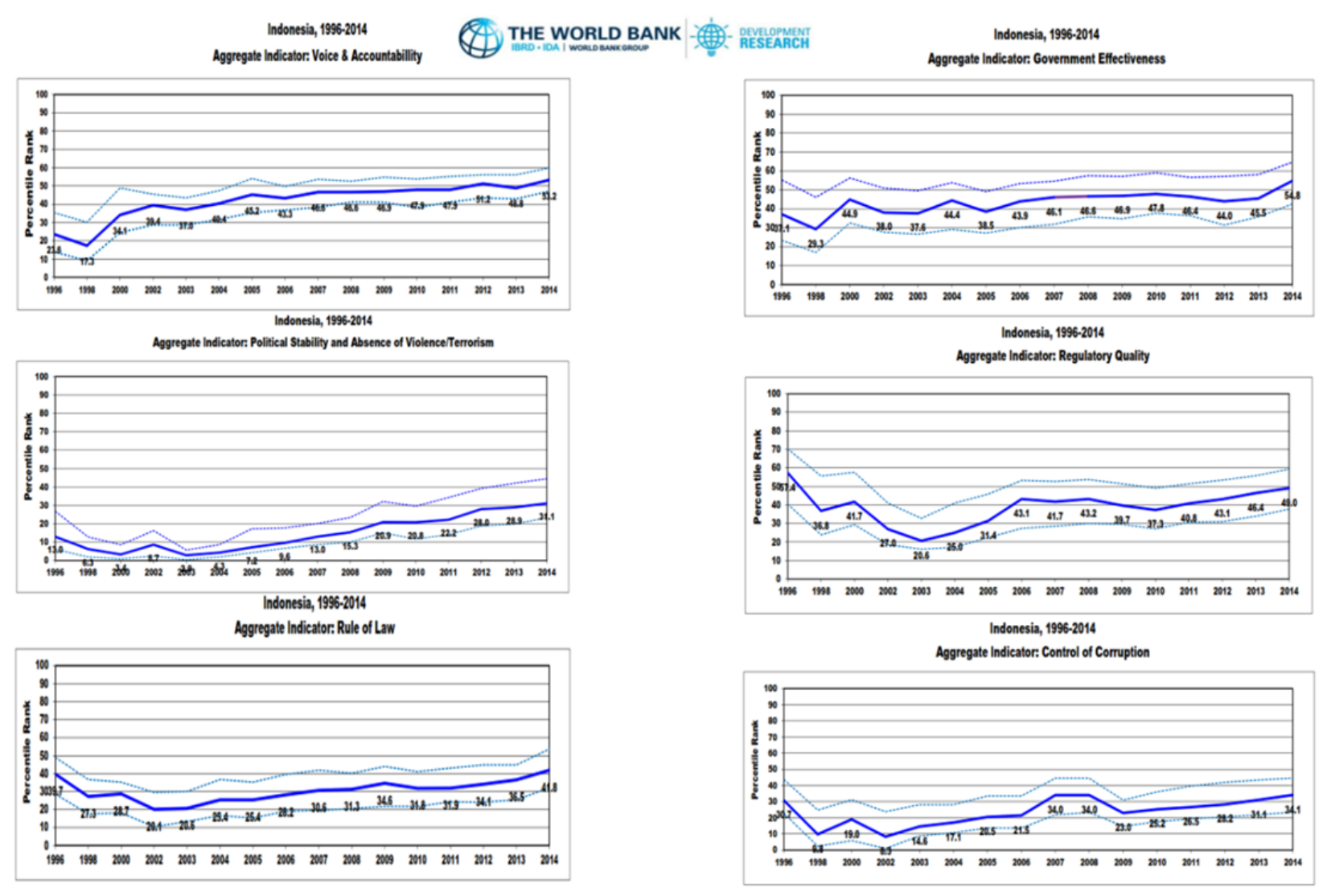

Figure 1. Indonesia on governance indicators

Source : World Bank

pattern of institution and governance that will be applied is a pattern based on the values and the principles of the noble past which is still relevant and in accordance both for present and the future.

c. Culture; Cultural development as the basis for the development of other sectors and this is addressed together to achieve a new civilization.

d. Land affairs: the effort to administer the land where the Sultanate ground and the Duchy ground are done through the registration process. This effort is intended to obtain physical data and judicial data of land as the basis for ensuring legal certainty and at the same time guarantee legal protection for both the Sultanate or the Duchy and the people who occupy the land.

e. Spatial planning; a guideline for governments and communities in the utilization and management of space based on cultural and social interests, and welfare.

As to whether or not the implementation of the law on Yogyakarta special administrative region has had an impact on governance as gauged by certain index, based on World Bank and UNDP analysis, there is an association between government Based on World Bank and UNDP, the indices show an improvement. Nonetheless, there is need for caution. As the World Bank itself warns these indices are just efforts to grasp briefly the governance condition of each country and there is need to delve into the details of every country to determine the underlying factors behind developments in Indices.

Based on World Bank 1996-2014 country data on governance indicators as shown in Figure 1, most indicators show an upward trend from 1998 onwards. Worldwide Governance Indicators (WGI) for each country, showing six dimensions of governance that include 1) Voice and Accounta- 


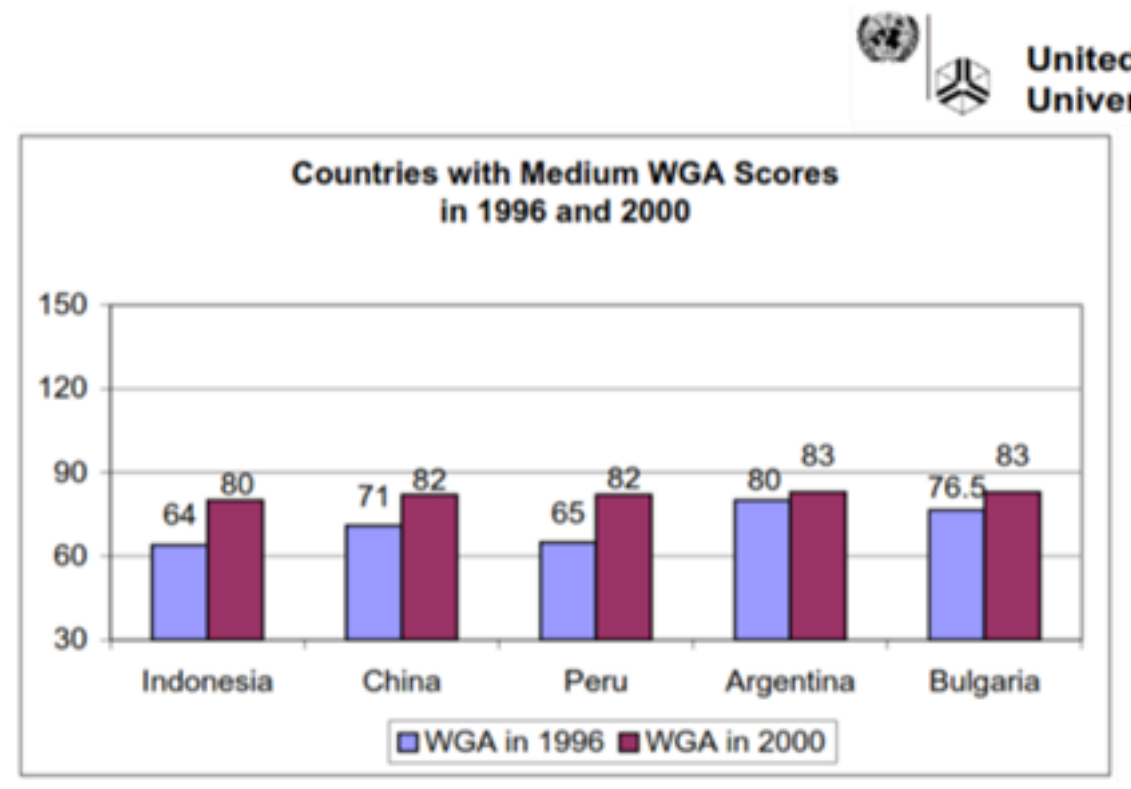

Figure 2. World Governance Survey by the UNDP and United Nation University

Source: UNDP and United Nation University, 2002. Governance Performance: The Aggregate Picture

bility, 2) Political Stability and Absence of Violence/Terrorism, 3) Government Effectiveness, 4) Regulatory Quality, 5) Rule of Law, and 6) Control of Corruption for over 200 countries and territories. This is an indication that good governance in Indonesia has increased since the reformation era.

Figure 2 depicts good governance indicators of Republic of Indonesia during the 1996-2000 period. UNDP and United Nation University report findings that show after the collapse of Suharto 's regime and ushering in of a political transition that steered the country of the 1997/1998 devastating economic crisis, Indonesia has since registered improvements on all the six indicators of governance. In 2000, in the wake of adopting democracy and decentralization, UNDP and United Nation University find an improvement in the score of Indonesian good governance performance enabling it to fall into the category of medium World Governance Aggregated (WGA)

To delve into components of Indonesian governance index, we can use governance partnership reform, which is UNDP institution that was formed in 2000 and became an independent legal entity in 2003. The goal of the agency is to improve governance through the enhancement of expertise and support from all sectors. In 2012, part- nership for governance reform released its Indonesia governance 2012. The annual index contains national and provincial components. The index has become increasingly important in the aftermath of the implementation of the decentralization policy in 2001 . This is because, developments in the index point to the direction of national and regional development.

The Index measures on the basis of a three tier perspective interalia: arenas, principles and indicators. It is structured into three stages that are first, 89 indicators, second, 6 principles and third, 4 arenas as introduced later.

The index measures several arenas of local governance in Indonesia that include political policy makers (government arena), policy implementers (bureaucracy arena), society (civil society arena), and business actors (Economic Society).

\section{Partnership for Reform Methodology in compiling the governance index.}

The index is measured on the basis of four arenas, which are assessed on the basis of six principles. The six principles in turn are analyzed on the basis of 89 indicators. Each arena is defined to provide similar logical framework and identification of the role it plays in governance practices. The scope 
Table 1. Part of the list of Indicators for Yogyakarta Governance Index

\begin{tabular}{|c|c|c|c|c|c|c|}
\hline No & Code & Indicator & Objective & $\begin{array}{l}\text { Direct Obser- } \\
\quad \text { vation }\end{array}$ & Questionnaire & Weight \\
\hline & & Government & & & & 0.302 \\
\hline & & Participation & & & & 0.120 \\
\hline 1 & GIP1 & $\begin{array}{l}\text { Average number of proposed district develop- } \\
\text { ment program accommodated in Province De- } \\
\text { velopment Planning Deliberation Meeting }\end{array}$ & & & V & 0.170 \\
\hline 2 & GIP2 & $\begin{array}{l}\text { Quality of Public Hearing in DPRD (local par- } \\
\text { liament) in the Deliberation of Provincial Reg- } \\
\text { ulations }\end{array}$ & & & V & 0.156 \\
\hline 3 & $\mathrm{G} 2 \mathrm{P} 1$ & $\begin{array}{l}\text { The quality of public hearings to discuss Local } \\
\text { Budget }\end{array}$ & & & V & 0.219 \\
\hline 4 & G3P1 & $\begin{array}{l}\text { Quality of Governor consultation forum with } \\
\text { stakeholder }\end{array}$ & & & V & 0.092 \\
\hline 5 & G4P1 & $\begin{array}{l}\text { Quality of public complaint channels to } \\
\text { strengthen DPRD monitoring function }\end{array}$ & & & V & 0.199 \\
\hline 6 & G4P2 & $\begin{array}{l}\text { Quality of DPRD Public Engagement in con- } \\
\text { ducting monitoring function }\end{array}$ & & & V & 0.164 \\
\hline
\end{tabular}

Adopted from Kemitraan, 2012: 59

of definition of each arena is presented below (Kemitraan, 2012:49): (summarize the arenas to prevent a break in the article please for the reader (continuity).

a. Government consists of policy making bodies that include the executive and legislative branches.

b. Bureaucracy relates to the implementing authority of government policies, hence that serves as the intermediary between the government and the general public.

c. Civil Society constitutes nongovernmental, not-for-profit: organizations, voluntary (formal and informal) associations, foundations, labor unions, professional associations, and education and research institutes.

d. Economic Society consists of business entities and associations that aim for profit and the protection of business interests through the conduct of economic exchange and production, and advocacy for better business climate. Meanwhile, the six principles, which are selected on the basis of suitability with Indonesian socio-political context (2012:50) are: (summarize the princi- ples, rather than enumerate or list them). One paragraph is enough for that.

e. Participation: the level of involvement of the stakeholders in the decisionmaking processes

f. Fairness: condition where the policy and programs taken in governance are applied fairly (without discrimination) to everyone without consideration of his/her status, racial background, religious affiliations, or sex.

g. Accountability: condition where public officials appointed or elected will be responsible for their conduct and responsive to the demands of the public

h. Transparency: condition where decisions taken by public officials are clear and open for the community to observe, scrutinize and evaluate

i. Efficiency: condition where the policies and programs implemented have utilized the resources- human, financial and time - in an optimal manner

j. Effectiveness: whether the objectives of the policies and programs (output) have been achieved in line with the intended purpose (constitutional man- 
Achmad Ubaidillah - A Study of Good Governance Index in Yogyakarta Special Region ...

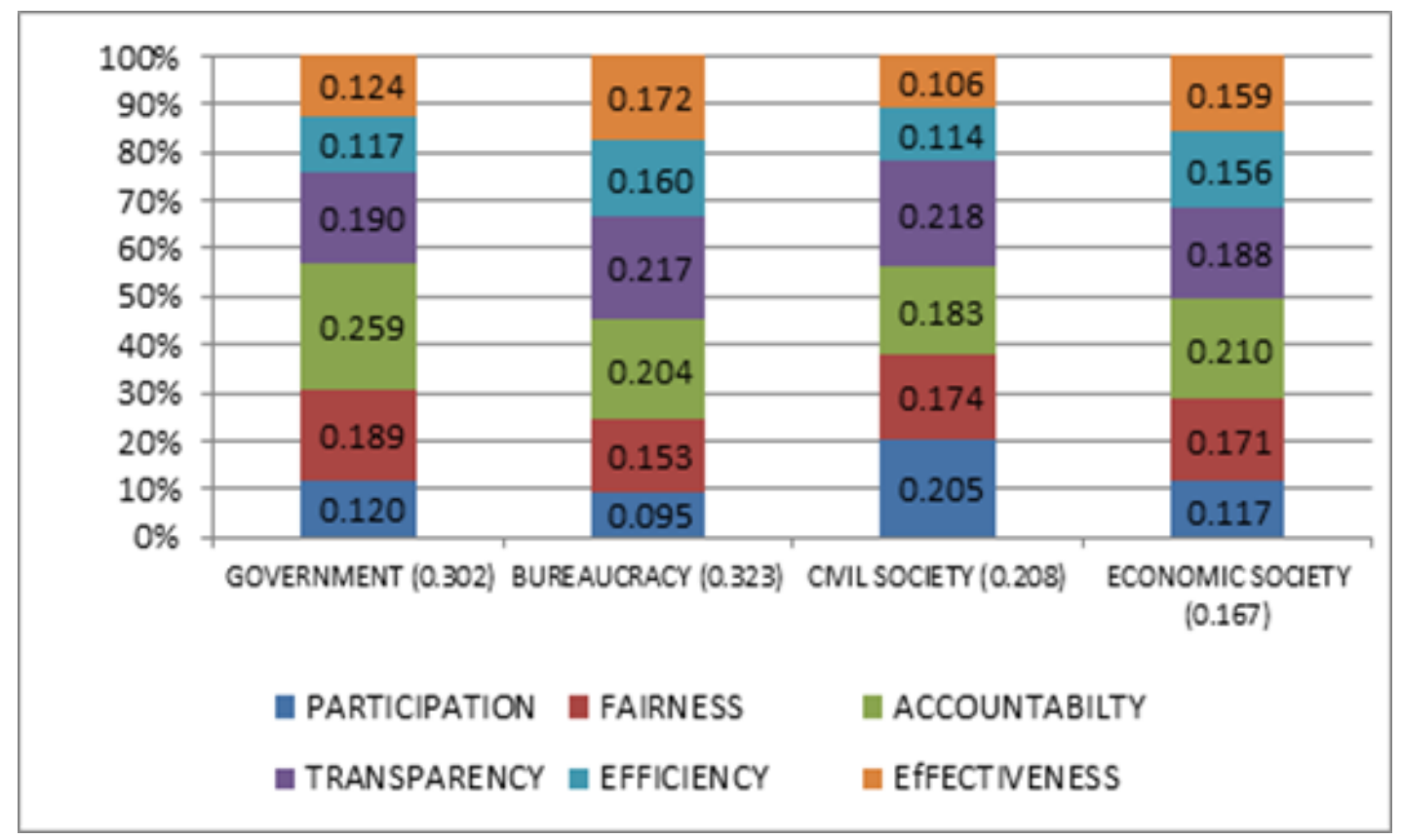

Figure 3. Weight of 6 Principles within each Arena

Source: Kemitraan, (2012:54)

date - communities that are intelligent, prosperous, just and civilizedbecomes the parameter)

And as regards the 89 indicators that are used to measure the six principles, they are drawn from e functions of the areas, i.e. government, bureaucracy, civil society, and economic society. The number of indicators varies from one principle to the other in each area. This research used 89 actionable indicators of good governance as shown in the Table 1. You don't have to list the indicators, what is important is your ability to show a connection and progression from arenas, principles, and indicators. Here is shown a part of the whole list of 89 indicators, indicator 1-6. This shows the indicators for the principle of participation for the arena of government. In the original list there follow other five principles with several indicators for each. Then likewise other three arenas with the same six principles with relevant indicators follow. The decision making process of indicator selection is based on the following criteria (Kemitraan 2012:52):
a. Significance,
b. Relevance to provincial authority,
c. Availability of data,
d. Discriminating power, and
e. Commonality across provinces

Indicators are analyzed either by using objective evidence or direct observations by experts or answers to questionnaires given to experts.

Thus, based on UNDP methodology experts in the four arenas (bureaucracy, civil society and economic society) review indicators that were used in the development of IGI. Nonetheless, partnership for governance reform also invited other experts from statistics, governance, research methodology, and academicians, were also involved in the exercise in order to provide critical review of the overall scheme and methodology.

Obviously the contribution of arenas, principles and indicators to good governance varies. Therefore, one of the key steps to take before using the indicators is to determine the weight of each arena, principle and indicator. The weighting method employed here is the Analytical Hierarchy Procedure (AHP). "AHP is a mathematic/statistic method indicated by judgment/opinion of experts (well-informed persons) towards the contribution of each arena, principle and indicator. Through pair-ways comparison each arena, principle and indicator is compared to one another. The result of comparing process is then processed using mathematical/statistical method to generate numerical weight 


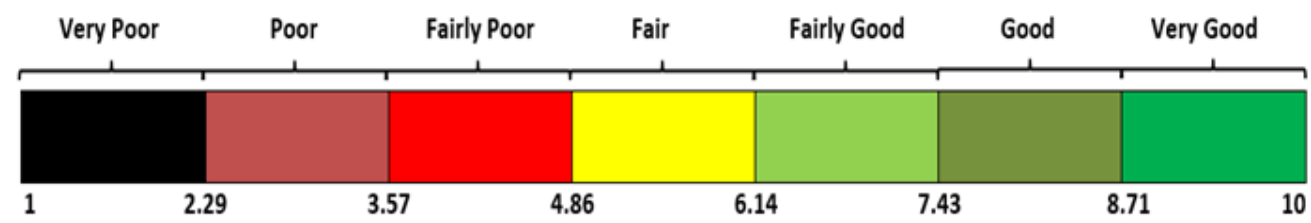

Figure 4. The index scale

Source: Kemitraan, (2012:56)

1" (Kemitraan 2012:53) as shown in Figure 3.

The compilation of the index is based on two types of data: objective data and perception/subjective (primary) data. Objective data comprises various formal and published documents, such as statistics data, Local Budget, Local Planning Document (RPJMD), Accountability Report (LKPJ), Financial Statement (PPUAS/KUA), Local Statistics Books, government records of activities, and so on. Meanwhile, perception data is compiled from answers to questionnaires that are filled out by resource persons (well-informed persons) who are strictly selected through certain criteria emphasizes their expertise and knowledge ability about the indicators being measured (Kemitraan, 2012: 54).

A normative approach is used in creating the index score the scale ranges from 1 to 105.50 being regarded as median as shown in the Figure 4. The performance of Yogyakarta on a certain arena, principle and indicator can be read from the scale. Therefore, a score of 5.50 (between the range of 4.86-6.14) is categorized as fair 1; the level above 3.57 up to 4.86 is categorized as fairly poor; while the score that is higher than 6.14 to 7.43 is categorized as fairly good (Kemitraan, 2012:56).

\section{RESULTS AND DISCUSSION}

We will now proceed with the comparison of governance indicess of Yogyakarta province for 2012 and 2016. As mentioned above, the values for 2012 are taken from Kemitraan's IGI report and those for 2016 are based on calculations the author made by using Kemitraan's IGI methodology. The author paid visits to such institutions as local parliament (DPRD), Local
Planning Bureau, Provincial Office, Local Bureau of Statistics, Education Office, and Local Chamber of Commerce. In addition, the author made consultations with lecturers, researchers, and journalists. Secondary data collection was obtained from published reports and documents, while questionnaire was used to collect data on perception.

\section{The comparison of Yogyakarta govern- ance index in 2016, 2012 and national av- erage 2012}

Figure 5 shows that the governance index of Yogyakarta special region in 2012 was 6.80, which is still far below the maximum score of 10. Nonetheless, even if Yogyakarta special region achieved the highest score, its governance index would only attain the fairly good level. The index in 2016 increased to 7.93, form fairly well to good level. What is also important to note is that the governance index of Yogyakarta in 2016 was also higher than the national average in 2012.

The increase in increasing Yogyakarta governance index is very interesting for analysis, especially in light of the enactment of Yogyakarta special administrative province law No. 13/ 2012. The 2012 index is based on conditions that prevailed prior to the enactment of the special status Law No. 13 of 2012 for Yogyakarta administrative region. With respect to arenas and principles, the performance of governance indicators after the enactment of Law No.13/2012 on Yogyakarta special province, shows improvement. This is evident in the level of democracy index which increases to the good level, and e institution performance accountability, which rises to grade "A".

Thus, developments in good governance indicators in Yogyakarta province is an interesting topic to study. This is more so, in 


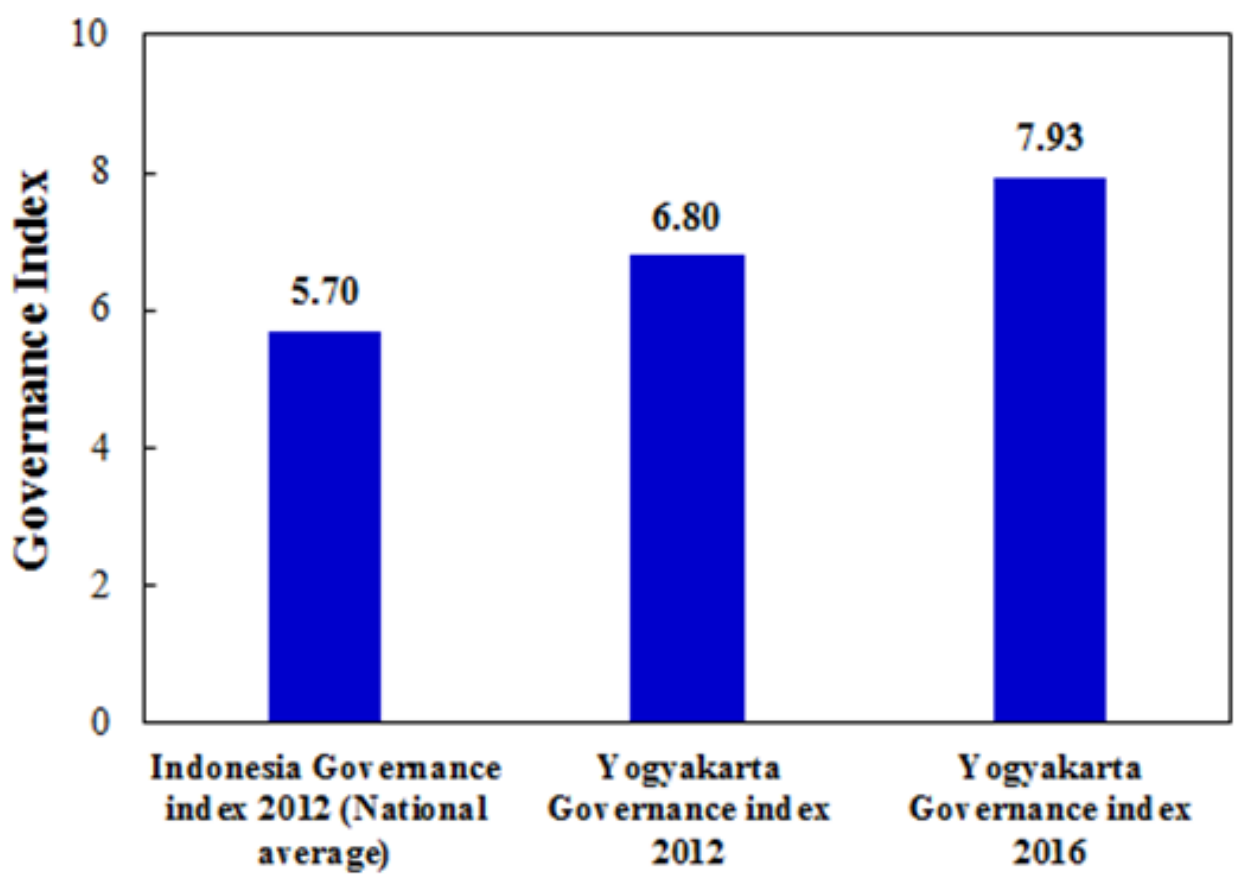

Figure 5. The comparison of Yogyakarta governance index

Source: The Indonesia governance index of 2012 and The Yogyakarta governance index of 2012 based on e Kemitraan's calculation and Yogyakarta governance index of 2016 Author's calculation

the aftermath of the enactment of special status Law No. 13 / 2012 d. One hypothesis is that the enactment of e Law No. $13 / 2012$ conferred substantial authority on Yogyakarta province to formulate its regulatory framework and policies, hence enhanced the ability of the provincial administration to direct the pace of local development. If that is the case, there is need to determine the impact which the enactment of the Law No.13/2012 had on determinants of governance index, which are so, the four arenas and six principles that are measured by 89 . However, the work is for another research paper.

\section{The Analysis of Arenas Level}

We will now see the components of the governance index to determine the relative contribution of the four arenas to the increase in the index for Yogyakarta. Figure 6 shows that the bureaucratic arena (8.24l) was the largest contributor to the index, followed by civil society arena (8.2), economic society (7.88) and the government arena (7.44), in that order. It is evident that all the arenas in Yogyakarta province for 2016 index are higher than values for 2012 index for
Yogyakarta and the national average index for 2012. There is significant difference in value of e arena of economic society on 2016 index and the value for the same arena in 2012. The economic society arena in 2016 increased by, 1.76 points from the value of the same arena on 2012 index. The same thing is evident on the civil society arena, the index of which was 8.2 on 2016 index, which is 1.48 points higher than the value on 2012 index.

Improvement on of arenas on Yogyakarta governance index may indicate that during four years since the enactment of Law No.13/2012 on Yogyakarta special status, Yogyakarta provincial government has been able to make significant improvements in e the bureaucracy, e economic society and civil society through innovative policies. One hypothesis for the change is that the enactment of Law No. 13/ 2012 has equipped Yogyakarta government with the capacity and flexibility required to manage institutions through conducting bureaucratic reforms, which process has led to improvement in the delivery of public services to society. Based on evidence obtained from official documents from Yogyakarta govern- 


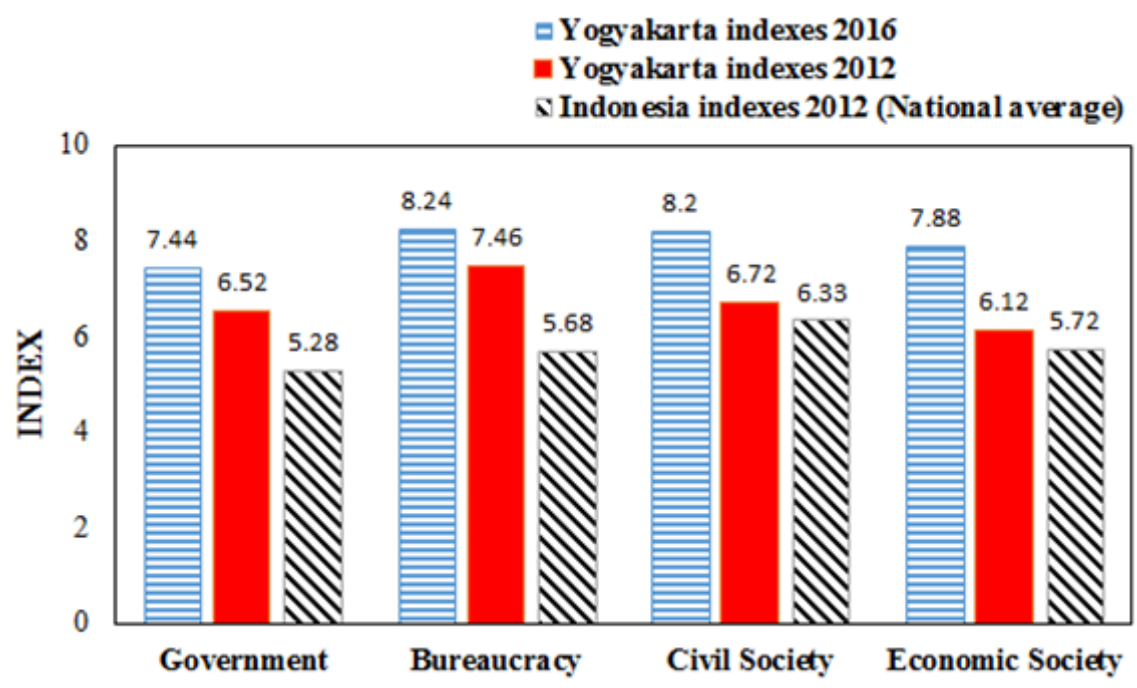

Figure 6. The Yogyakarta governance index

Source: Data Analysis

ment, there is a possibility that the above hypothesis may be correct. Officials documents indicate that Yogyakarta province has formulated a road map of bureaucratic reform that covers 8 areas, that include: 1). Management, 2). Organization, 3). Legislation law, 4). Human resources, 5). Governance, 6). Accountability, 7). Monitoring and 8). Improvement in public service delivery, may be one of such areas that has benefited from the above reforms.

\section{The Comparison of Overall Principles}

Although the index has increased in every arena and has achieved good category level, observing the components at the level of principles shows that not all principles have improved. In this section a comparison among the principles in each arena will be observed to determine which principles have improved and which have not made progress in every arena. This is shown in Figure 712.

If we take an overview of Yogyakarta governance index of 2016, the performance of governance principles in Yogyakarta tends to vary in each arena as shown in Table 2. Some of governance principles were able to register highest level. The (very good) (10), for example principles of participation, accountability and transparency in the bureaucracy arena. However, some principles registered the lowest index such as the effectiveness principle for the government arena that falls a fairly poor category

\section{Analysis of the participation principle}

The implementation of participation principles registered very good level in the bureaucracy arena and 'good' in the arena of government, civil society and economic society. Meanwhile bureaucracy arena achieved the maximum index (10.00) that is very good. Overall, the participation index shows an improvement in 2016 compared with the performance in 2012 at both Yogyakarta province and national level (Figure 7).

This could be evidence that bureaucratic reforms, which Yogyakarta government has implemented have involved the participation of Yogyakarta society. For example, the existence of public complaints center (UPPM) in the provincial revenue collection, health, education and poverty eradication has been widely used by the Yogyakarta society as a place to report and provide input to the government. Therefore, Yogyakarta province has witnessed a two-way communication between the government which is the provider of services, and the public, who are service users.

\section{Analysis of the fairness principle}

The implementation of the fairness principle as reflected in three arenas: bureaucracy, civil society and economic society 
Achmad Ubaidillah - A Study of Good Governance Index in Yogyakarta Special Region ...

Table 2. Overview of Yogyakarta governance index of 2016

\begin{tabular}{lcccccc} 
& Participation & Fairness & $\begin{array}{c}\text { Accountabil- } \\
\text { ity }\end{array}$ & $\begin{array}{c}\text { Transparen- } \\
\text { cy }\end{array}$ & Efficiency & $\begin{array}{c}\text { Effective- } \\
\text { ness }\end{array}$ \\
\hline Government & 8.37 & 6.04 & 8.14 & 8.81 & 8.29 & 4.40 \\
\hline Bureaucracy & 10.00 & 8.31 & 10.00 & 10.00 & 5.44 & 5.47 \\
\hline Civil Society & 8.20 & 8.20 & 8.20 & 8.20 & 8.20 & 8.20 \\
\hline $\begin{array}{l}\text { Economic } \\
\text { Society }\end{array}$ & 8.20 & 8.20 & 8.20 & 8.20 & 8.20 & 6.16 \\
\hline
\end{tabular}

Source : Data analysis

arena shows improvement that falls into the category of 'good', while the government arena achieved the category of 'fair'. Nonetheless, the performance of government arena in 2016 index shows marked improvement from that in 2012, despite merely registering fair level. (Figure 8).

The issue that relates to fairness in the government arena concerns fairness in the distribution of the local budget (APBD). The existence of Law No.13/2012 on Yogyakarta special province, equips the province with the authority to use special funds to finance policies and programs that underpin the five pillars of Yogyakarta special status. Thus, the existence of the special status law had made possible the availability of funds in the local government budget, which can be distributed equitably to key priority sectors. The fairness principle shows an upward trend in the four arenas. . This may indicate improved cooperation between the governor and legislature, in formulating fair local government policies.

\section{Analysis of the accountability principle}

Figure 9 shows that the implementation of accountability principle in the bureaucracy arena attained 'very good' level (10.00) and 'good' level in government, civil society and economy society levels. Comparison of accountability principle for 2016 governance index with that in 2012 index, shows that accountability in the bureaucracy, civil society and economic society arenas shows the an upward trend. Nonetheless, accountability index in the government arena in 2016 index shows a slight decline which however is not significant.
However the achievement of 'good 'on accountability in the government arena is largely as a consequence of the evaluation results on government accountability issued by ministry of state apparatus and administrative reform which awarded Yogyakarta province grade "A" (Table 3 ).

\section{Analysis of transparency principle}

The implementation of transparency principles registers 'very good' level in the bureaucracy arena and 'good' grade in the government, civil society and economic society arenas. Bureaucracy arena achieves maximum score of 10 , which is very good. Overall, transparency index shows an improvement in 2016 compared with the performance in 2012, as well as national average for 2012. (Figure 10).

This could be evidence that bureaucratic reforms that Yogyakarta government has made are working (see 3.2, of 8 areas) This is because the reforms have created a transparent and easily accessible public service delivery system to society. A good example of that is the fact that today, financial statements issued by local government offices are easily accessible to the public via the official website of Yogyakarta provincial government. Thus, the public has the opportunity to provide inputs into reports that are issued by the provincial government offices.

\section{Analysis of efficiency principle}

The efficiency principle in the government, civil society and economic society arenas shows an upward trend (Figure 11). However, the bureaucracy arena for 2016 shows no change from the value registered 


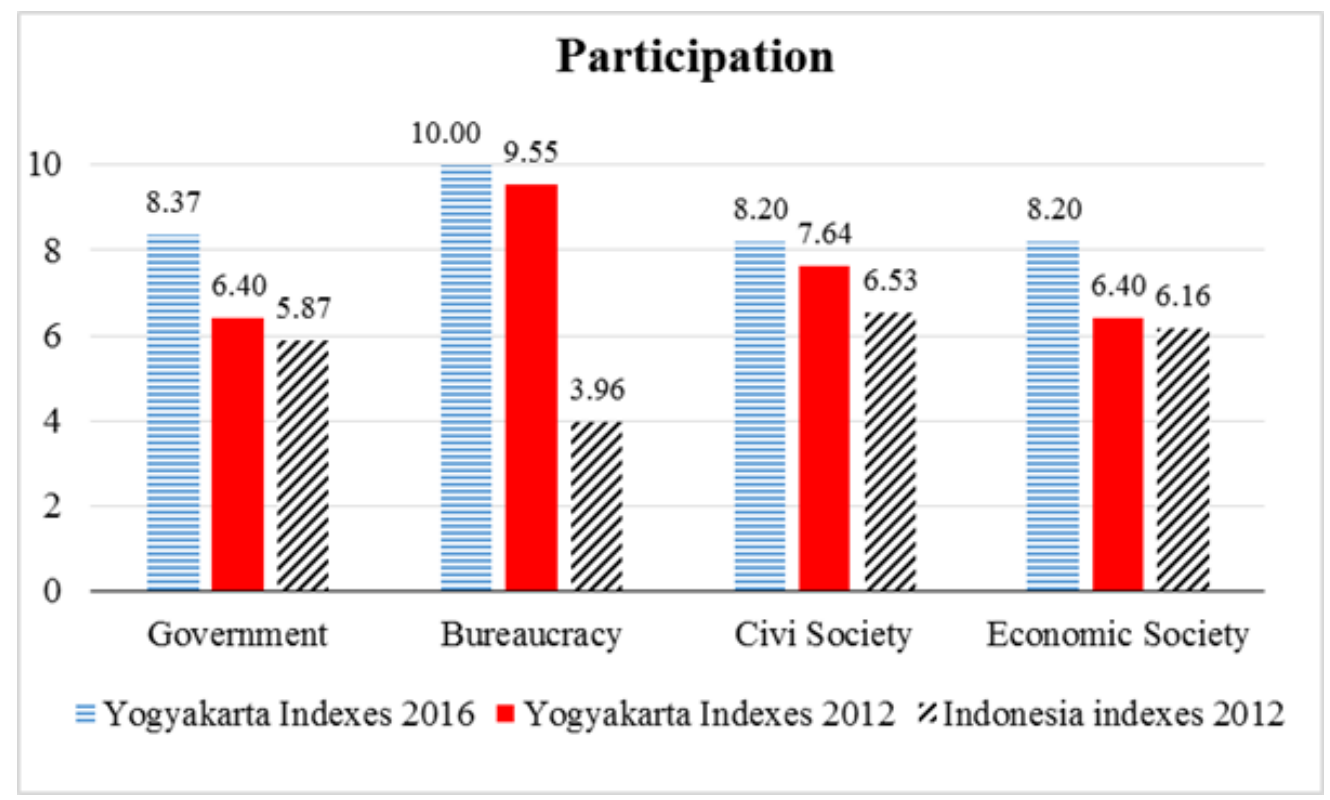

Figure 7. The participation index in different arena

Source: Data Analysis

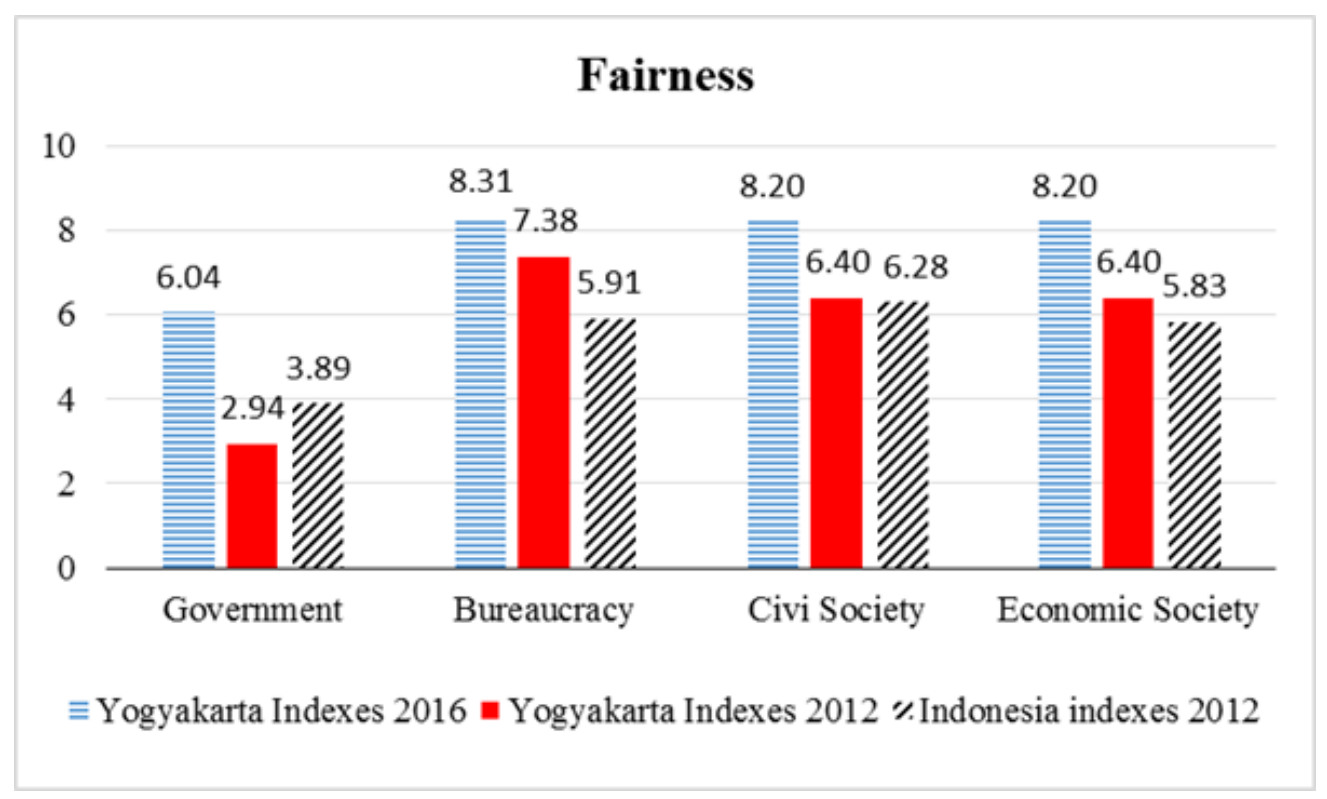

Figure 8. The fairness index in different arena

Source: Data Analysis

in 2012. Moreover, the value of the index is still that the national average.

One possible explanation is that that the ratio of civil servants overhead expenditure (direct and indirect) was lower than the total public expenditure in the provincial government budget (APBN). (This point is far from clear, Try to elaborate it please for the reader)
Analysis of the Effectiveness principle

The effectiveness principleshows a declining trend in the government and bureaucracy arenas, but registers an upward trend in the civil society and economic society arenas (Figure 12).

A decline $\mathrm{m}$ in the effectiveness score in the government arena could the result of rising poverty incidence and unemployment 
Achmad Ubaidillah - A Study of Good Governance Index in Yogyakarta Special Region ...

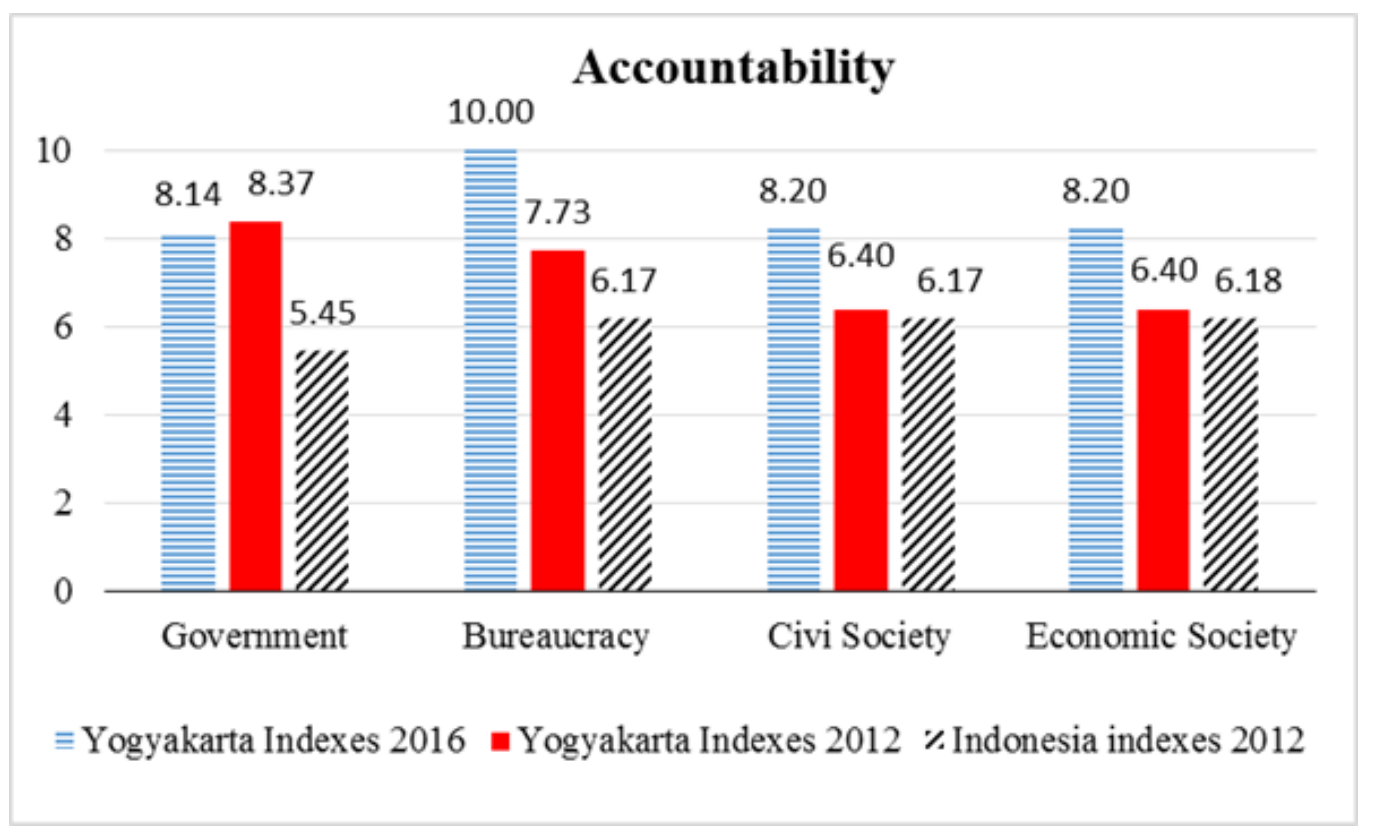

Figure 9. The accountability index in different arena

Source: Data Analysis

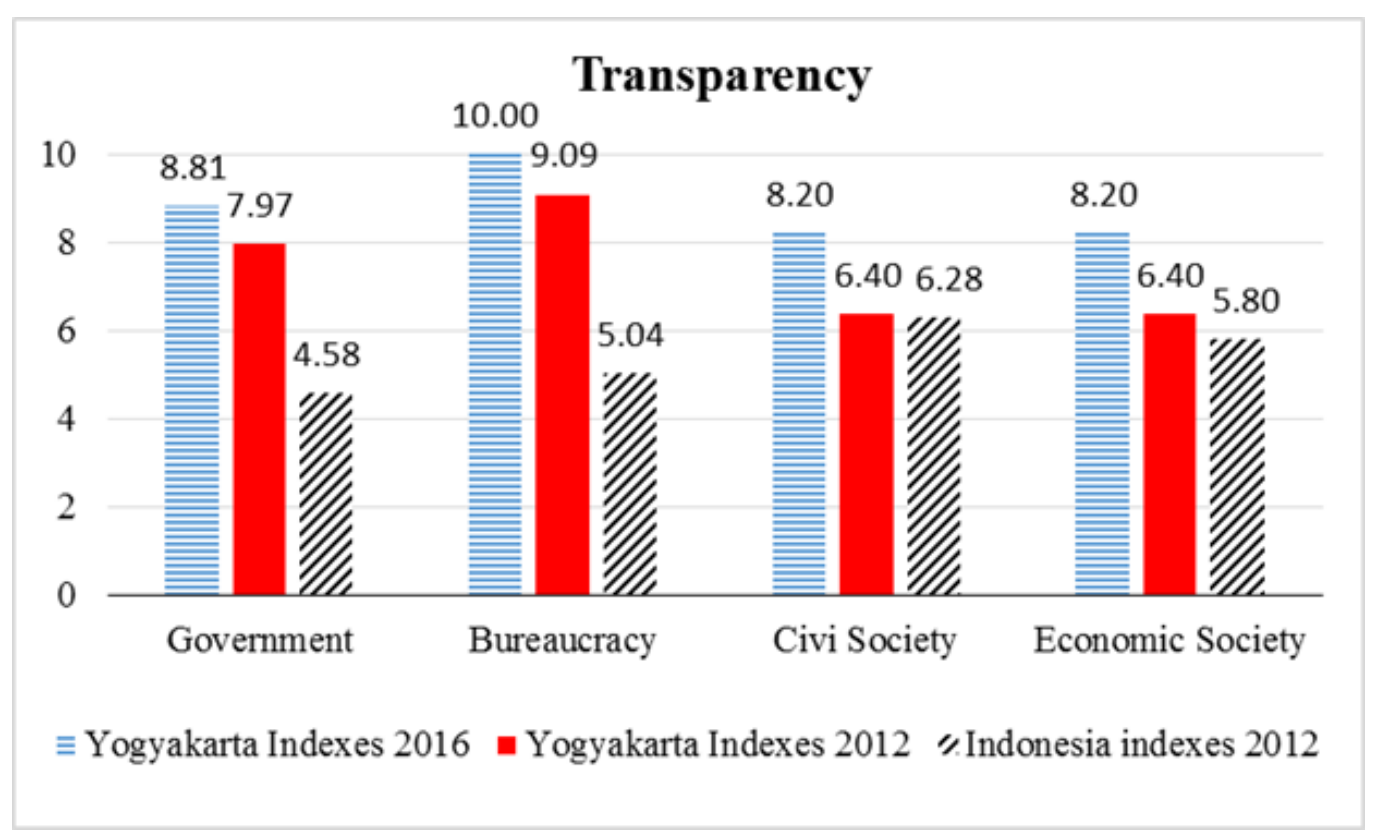

Figure 10. The transparency index in different arena

Source: Data Analysis

rate in 2015. Meanwhile, the increase in effectiveness score in the civil society arena may be attributable to the success of corruption eradication efforts and the impact of the contribution of civil society in improving the quality of public service delivery. Improvement in the effectiveness index in the economic sector may be as a result of the better performance of the business sector thanks to improvement in the conduct of business amid improved business climate conditions It can also be argued that improvement in the investment climate in Yogyakarta might be as result of enhanced social and political in the aftermath of the enactment of Law No.13/2012 on Yogyakarta special status. Unlike other provinces, Yogyakarta province does not hold direct gubernatorial elections, which have been associated with political and social instability in some provinces. 


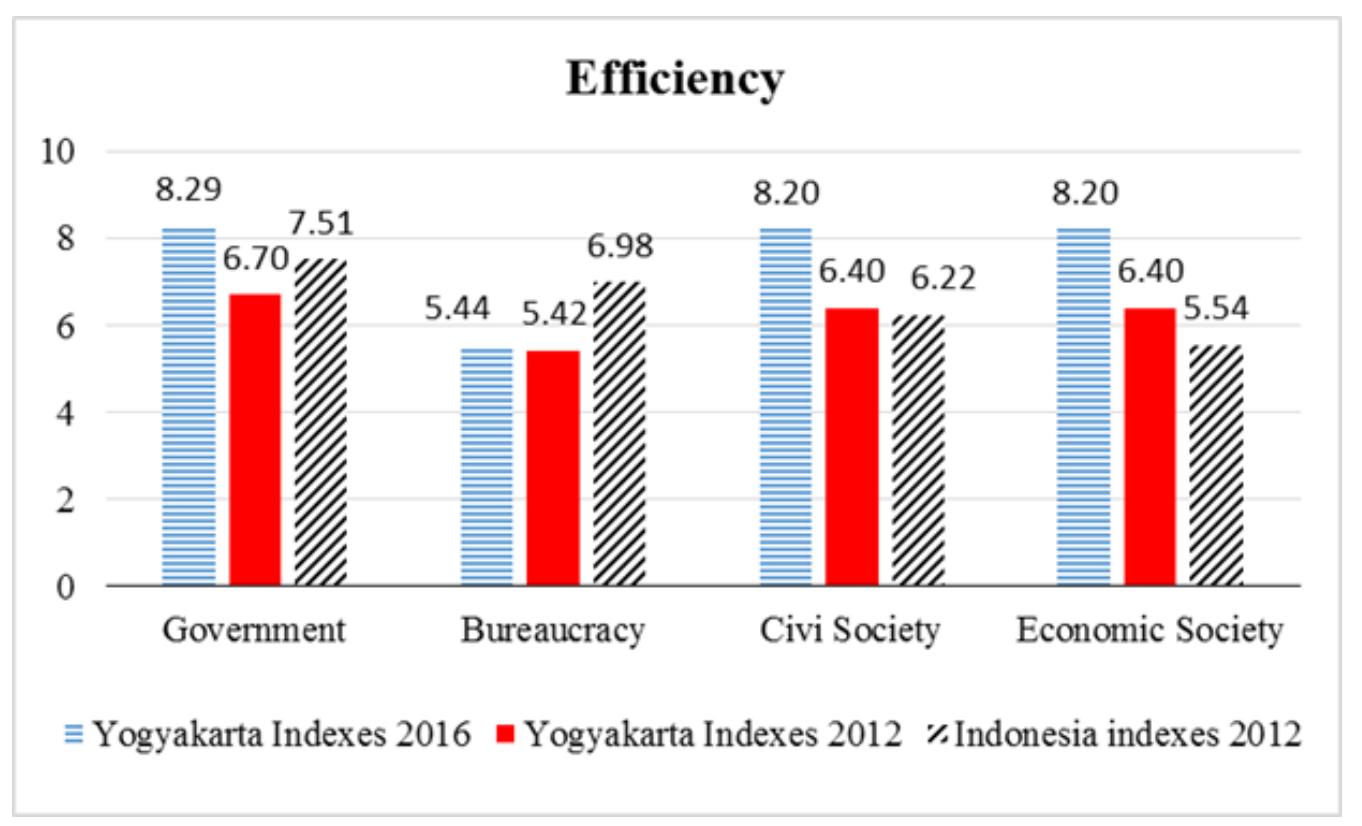

Figure 11. The efficiency index in different arena

Source: Data Analysis

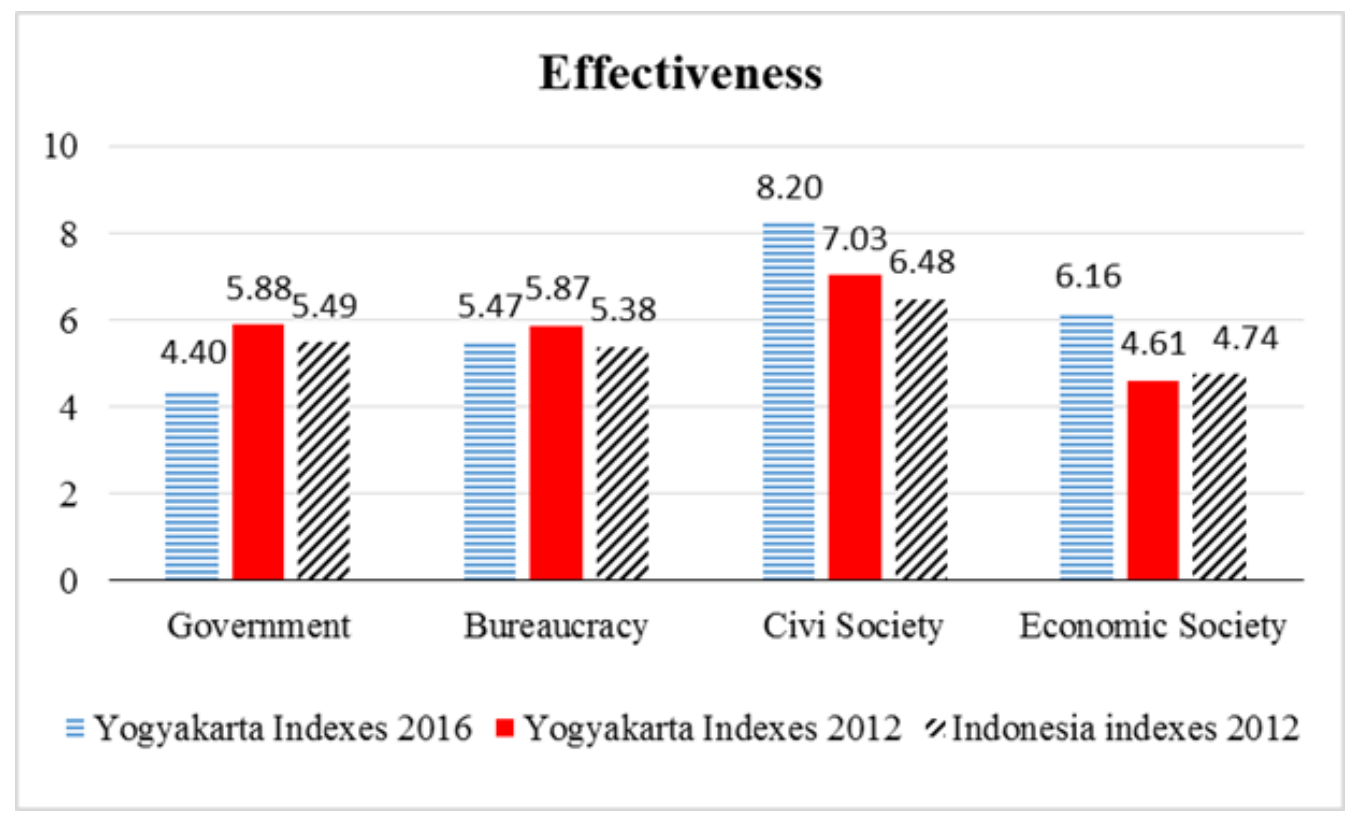

Figure 12. The effectiveness index in different arena

Source: Data Analysis

\section{CONCLUSIONS}

Yogyakarta province was kingdom during the colonial period ruled by the charismatic Sultan. Successive Sultans succeeded to transform the Kingdom into a province with the best administrative system in Indonesia. This is the seed /initial capital, which underpins the implementation of good governance in the province. The has assessed the state of good governance in Yogyakarta province in 2012 and 2016 , which also reflect the period prior and after the enactment of Law No.13/2013 on Yogyakarta special administrative province. The law among other goals aims at instituting good governance and social order to ensure unity in diversity within the framework of Unitary Republic of Indonesia. The law among other provisions, confers upon Yogyakarta provin- 
Achmad Ubaidillah - A Study of Good Governance Index in Yogyakarta Special Region ...

Table 3. The institution performance accountability report Yogyakarta

\begin{tabular}{|l|c|c|c|c|c|c|c|c|}
\hline & \multicolumn{4}{|c|}{ Before Act No. 13 of 2012 } & \multicolumn{3}{c|}{ After Act No. 13 of 2012 } \\
\cline { 2 - 9 } & 2008 & 2009 & 2010 & 2011 & 2012 & 2013 & 2014 & 2015 \\
\hline $\begin{array}{l}\text { The institution } \\
\text { performance } \\
\text { accountability } \\
\text { report }\end{array}$ & $\mathrm{C}$ & $\mathrm{C}$ & $\mathrm{B}$ & $\mathrm{B}$ & $\mathrm{B}$ & $\mathrm{A}$ & $\mathrm{A}$ & $\mathrm{A}$ \\
\hline
\end{tabular}

Source: The ministry of administrative reform and bureaucratic reform, 2015

cial government special authority in five areas. .

a. Results from comparing good governance index for Yogyakarta special province in 2012 (before the enactment of Law No.13/2013) and 2016 after the enactment of the law, shows that in general good governance has improved from 'fairly good' category to 'good' category, which the author associates with the change in social, economic and political context that came as a consequence of the implementation of the law in as far as it conferred on the provincial government streamlined authority in the five special areas.Based on this conclusion, the author proposes policy changes which have been made in the wake of the implementation of Law No.13/2012, to generate improvement in good governance in span of four years The five domains, which have been impacted by the enactment of Law No.13/2012, and have in turn contributed to improvement in good governance include: Political stability pathway: streamlined procedure to fill the position, status, tasks and authorities of the governor and vice governor, has had an a positive impact on political stability, hence source of sustainable development in Yogyakarta province.

b. Flexibility pathway: Yogyakarta government has become more flexible in managing institutions, conducting bureaucracy reforms and delivering excellent public services in Yogyakarta.

c. Special funds to pathway. The central government conferred upon granted: Yogyakarta government the authority to set up and use special funds in line with the special areas that are delineated in the Law on special status. Therefore, local government budget (APBD) has become better and equitably distributed Spatial planning pathway: The new law authorizes Yogyakarta government to control the spatial development in the province, which has led to improvement in spatial planning

\section{ACKNOWLEDGEMENTS}

The author would like to acknowledge the assistance and support provided by Kemitraan (Partnership for Governance Reform) Indonesia, Yogyakarta government and all those institutions and experts who kindly provided the necessary data that was used to calculate 2016 good governance index

\section{REFERENCES}

Green, K. (2005). Decentralization and Good Governance: The Case of Indonesia. MPRA Paper No. 18097, Munich Personal RePEc Archive.

Kemitraan, (2012) "Towards A WellInformed Society and Responsive Government" Executive Report Indonesia Governance Index 2012. Jakarta.

Pramusinto. A., 2006. Building Good Governance in Indonesia. Paper presented at the EROPA Conference: modernizing the Civil Service Reform in Alignment with National Development Goals, Bandar Seri Begawan Brunei Darussalam, and 13-17 November 2006.

Statistics Central Agency (BPS), 2014. Berita Resmi Statistik: Indeks Demokrasi Indonesia (IDI) 2014, No. 75/08/th. XV11, August 2015.

Statistics Central Agency (BPS) (2015). Indonesia Democracy Index 2015, Jakarta

The Republic of Indonesia (1945). The Constitution of 1945 Republic of Indonesia 
(UUD 1945). Jakarta.

The Republic of Indonesia (1950). The law of the Republic Indonesia Number 3 of 1950 concerning Establishment of The Special Region in Indonesia. Jakarta.

The Republic of Indonesia (2004). The law of the Republic Indonesia Number 32 of 2004 concerning regulates local government. Jakarta.

The Republic of Indonesia (1999). The law of the Republic Indonesia Number 22 of 1999 concerning decentralization. Jakarta.

The Republic of Indonesia (1999). The law of the Republic Indonesia Number 34 of 1999 concerning special region capital city of Jakarta. Jakarta.

The Republic of Indonesia (1999). The law of the Republic Indonesia Number 44 of 1999 concerning privileged Province Aceh. Jakarta.

The Republic of Indonesia (2001). The law of the Republic Indonesia Number 21 of 2001 concerning special autonomy for Papua Province. Jakarta.

The Republic of Indonesia (2012). The law of the Republic Indonesia Number 13 of 2012 concerning Yogyakarta privileg- es. Jakarta.

Utomo, Triwidodo Wahyu (2012) Building Good Governance through Decentralization in Indonesia. Retrieved from http:// www2.gsid.nagoya-u.ac.jp/blog/anda/ files/2012/01/7 tri-widodo-wahyu1.pdf

UNDP and United Nation University, 2002. Governance Performance: The Aggregate Picture. World Governance Survey (WGS) Project.

World Bank Institute. The Worldwide Governance Indicators (WGI) Project. http:// info.worldbank.org/governance/wgi/ index. asp

Yogyakarta province. (2012). The Mid-term Regional Development Planning (RPJMD) of Yogyakrta 2012-2017. Yogyakarta.

Yogyakarta province (2012). Academic Paper of Privilege status of Yogyakarta 2012. Yogyakarta

Yogyakarta province (2013). LAKIP of Yogyakrta 2013. Yogyakarta.

Yogyakarta province. (2016). The Review of Mid-term Regional Development Planning (RPJMD) of Yogyakrta 20122017. Yogyakarta. 